\title{
A Tribute to John Montague Gillett, 1918-2014
}

\author{
ERICH HABER
}

60 Baywood Drive, Stittsville, Ontario K2S 2H5 Canada

Haber, Erich. 2015. A tribute to John Montague Gillett, 1918-2014. Canadian Field-Naturalist 129(1): 90-96.

John Montague Gillett (Figure 1), or "Jack," as he was called by everyone, was born in Ottawa on 26 November 1918, the only child of Elizabeth and John C. Gillett, both of whom came from large families in England. Elizabeth left England as a lady's handmaiden on a passenger liner bound for the United States. She subsequently moved to Ottawa, and John joined her there. John was a machinist and Elizabeth worked as a chef in her early career.

Jack grew up in the Westboro area of Ottawa, where he explored with like-minded friends such as Lloyd Francis, former member of the Canadian Parliament and Speaker of the House. Jack and friends spent their holidays at Constance Bay and occasionally would cross the Ottawa River in a rowboat equipped with a sail. They would climb the escarpment ("the mountain") in an area that would become part of Gatineau Park, Quebec. For thrills, they would also dive into the turbulent waters at Hog's Back Falls, Ottawa.

Jack completed his secondary school studies at Glebe Collegiate Institute in 1937. At Glebe, he also learned shorthand and typing. This bode well for Jack because, while working part time after school cleaning up in the chemistry lab, he was asked by a staff member to type out his doctoral thesis, which was on a botanical topic. This kindled in him a lifelong interest in botany and taxonomy.

Jack joined the Royal Canadian Air Force and served both in Canada and England between November 1940 and September 1945. He initially wanted to be a pilot and trained to fly fighter planes while at the Gander Airfield in Newfoundland. However, after episodes of blacking out during training, Jack became a mechanic instead. When he was transferred to the Kirmington Airfield (Humberside International Airport), Lincolnshire, England, Jack worked as a radar mechanic on Lancaster Bombers. Unfortunately, this resulted in a partial hearing loss from the noise of the bomber engines that were being serviced.

Following his military service, Jack enrolled in biology at Queen's University, Kingston, Ontario (19451949). He used his veterans' allowance to fund his initial postsecondary education. In the course of his studies at Queen's, he served as an undergraduate assistant in general biology (1946-1947). During the summers of 1946-1948, Jack returned to Ottawa as a summer

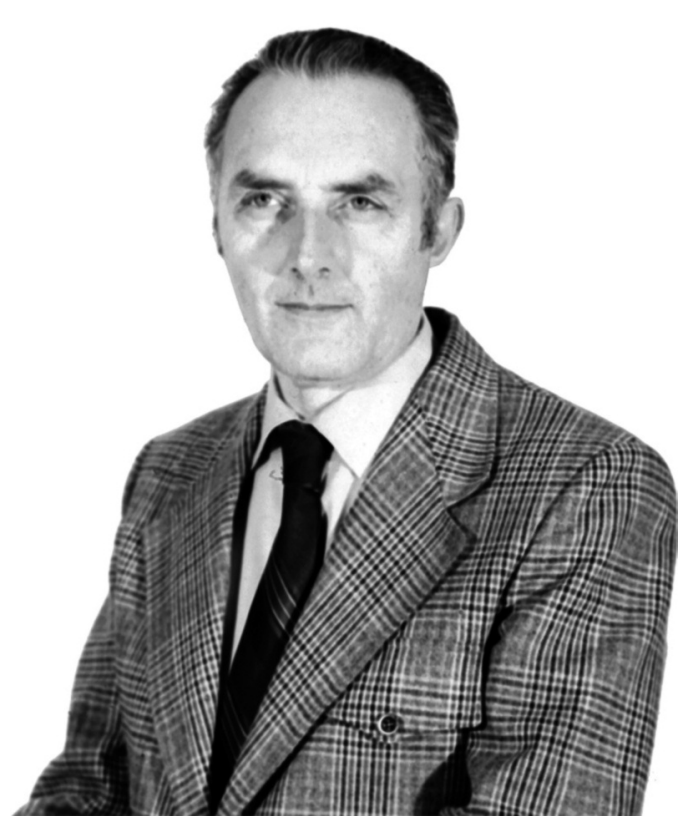

Figure 1. John M. Gillett, 1974. Photo courtesy of the Canadian Museum of Nature.

student planting trees in the Arboretum and working in the herbarium of the Division of Botany and Plant Pathology at the Central Experimental Farm (CEF), Agriculture and Agri-Food Canada (AAFC). In the summer of 1948, he was sent to Churchill, Manitoba, to assist in a northern survey project conducted for the Defence Research Board. After graduating from Queen's in May 1949 with an honours B.A. (biology, chemistry), Jack joined the staff at the CEF herbarium. In the fall of 1949, Jack took leave from his position and began studies for his doctoral thesis on the genus Gentianella at the Missouri Botanical Garden under the supervision of Robert E. Woodson. While conducting his research there and majoring in plant taxonomy and morphology, Jack also served as a herbarium assistant (1949-1951).

Jack received his Ph.D. on 8 May 1952 from Washington University, St. Louis, after completing his thesis entitled: A Revision of the North American Species of Gentianella (Figure 2). That same summer, he returned 


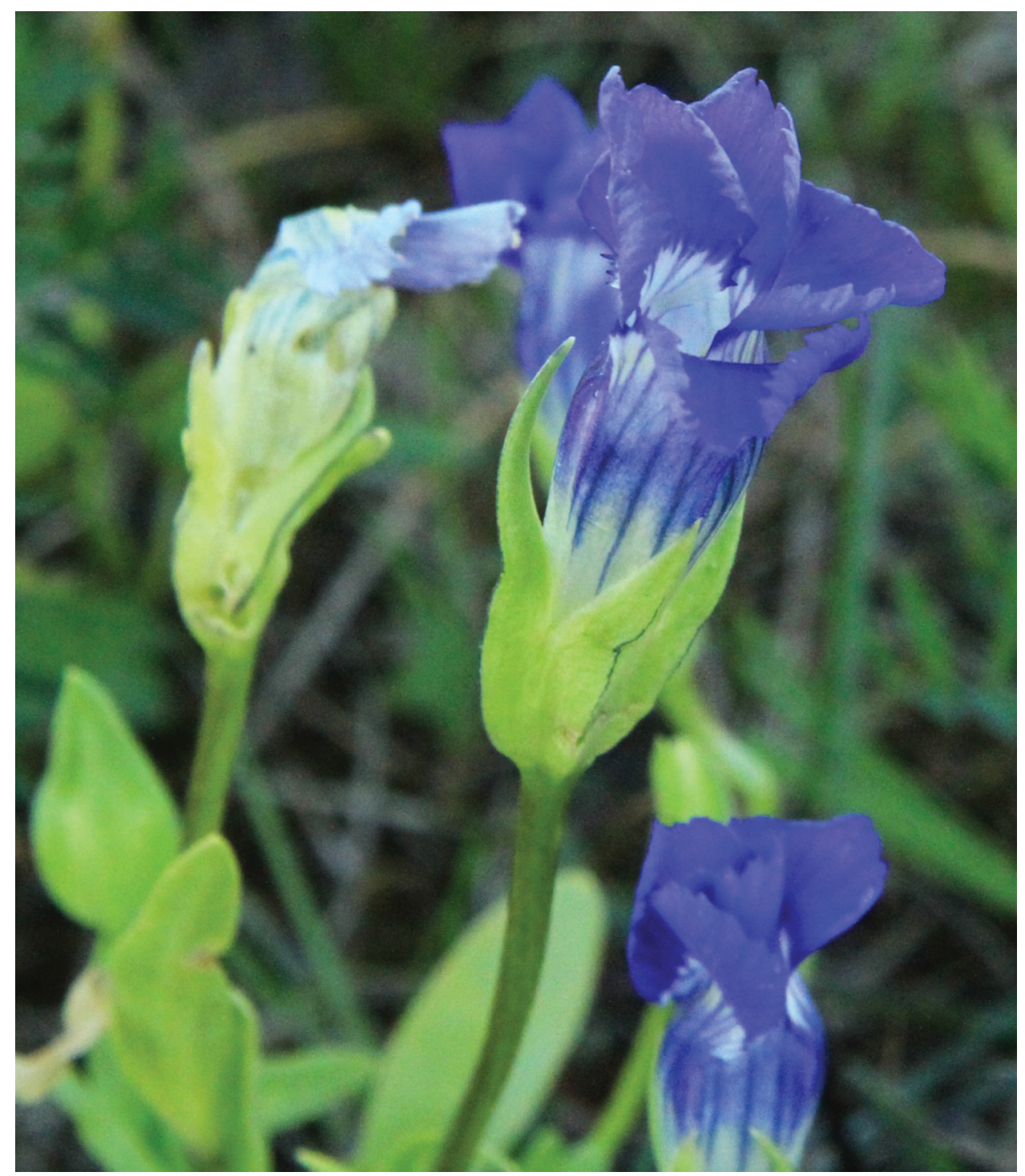

FIGURE 2. Windmill Fringed Gentian, a species studied by Jack Gillett and originally treated as Gentianella detonsa (Rottbøll) G. Don ssp. nesophila (T. Holm) J. M. Gillett. This was later transferred to the genus Gentianopsis. Photo: D. Brunton, Hawkes Bay, Newfoundland, Canada, 4 August 2014.

to Ottawa and began the first of his many field surveys (Cody et al. 1986), which included the vicinity of Marmora, Ontario (1952); along the proposed route of the St. Lawrence Seaway, with W. G. Dore (1952, 1953); Crater Lake, Labrador, in connection with the National Geographic Society and the Royal Ontario Museum (1953); Florida, with W. M. Bowden (1954); the area around Québec City (1955); southern Ontario (1957); Churchill, Manitoba (1958), to prepare for an International Botanical Congress field trip for which he was host (1959); along the Alaska Highway in northern British Columbia, southern Yukon, and the Ogilvie
Mountains with J. A. Calder (1960); southern Ontario for studies on legumes (1961); western Canada and United States (1962, 1963, 1964, 1966, 1970); and a floristic study of Gatineau Park, Quebec (1967, 1968).

Jack's early surveys, checklists, and plant collections serve as useful tools that now provide an insight into floristic changes that have occurred in areas explored decades ago. One such important survey conducted with Bill Dore in 1952-1953 along the proposed St. Lawrence Seaway, provides an in-the-nick-of-time inventory of a significant ecological corridor that no 
longer exists. This inventory remains as the most comprehensive ever conducted in southeastern Ontario.

Jack was an amiable field companion according to one of his colleagues from the former Plant Research Institute, AAFC (Ted Mosquin, personal communication). He recalled with much affection his time with Jack exploring the mountains of the American Great Basin collecting clovers (Trifolium spp.). Jack was a light-hearted and fun-loving companion on botanical collecting trips. He would take great delight when encountering a species he had not seen before, especially of rare native clovers, and would let out a boyish shriek of joy. At times of considerable risk, walking along the edge of a cliff, a steep slope, or in areas of bear signs, Jack would exclaim, "Never fear, Bullwinkle is here." This is in reference to an early animated TV show featuring Bullwinkle, a moose with large antlers, and his friend Rocky, a flying squirrel. Ted also benefitted, as others have, from Jack's helpful nature in providing assistance with plant identifications. He was always keen to chat with botanists and to provide encouragement and advice.

In 1972, Jack left the Plant Research Institute at CEF to become a curator and head of the vascular plant section of the herbarium at the National Museum of Natural Sciences (now Canadian Museum of Nature). In his new role, he undertook to reorganize species alphabetically within genera rather than follow the existing scheme based on grouping species by presumed affinities. Over the course of his years at the museum, Jack continued his work on the local flora. This included preparing an extensive manuscript on the flora of Gatineau Park, which unfortunately was never published in its entirety. Several groups of plants from the manuscript, such as the clovers, asters, goldenrods, and violets, were published in Trail \& Landscape, a quarterly newsletter of the Ottawa Field-Naturalists' Club. Jack also published a Checklist of the Vascular Plants of the Ottawa-Hull Region. The second, updated version of this checklist, revised with David White in 1978 (see bibliography), served, for decades, as an important tool for floristic work in the region and for landscape conservation and protection. Jack also continued with his taxonomic studies of various plant groups at the museum. He retired from the museum in 1983 (Figure 3), but maintained his affiliation as curator emeritus.

Jack was a "field biologist," who applied knowledge gained in the field to his systematic studies. This approach provided a better understanding of the species in nature and helped in the recognition of new taxa. In his work with gentians (Gentianaceae), Jack described two new subspecies: Pribilof Dwarf Gentian (Gentianella tenella (Rottbøll) Börner ssp. pribilofi J. M. Gillett); and Yukon Fringed Gentian (Gentianopsis detonsa ssp. yukonensis (J. M. Gillett)).

Among other genera Jack studied, he specialized, in particular, in clovers (Trifolium spp.). His contributions to this important group, which includes many econom-

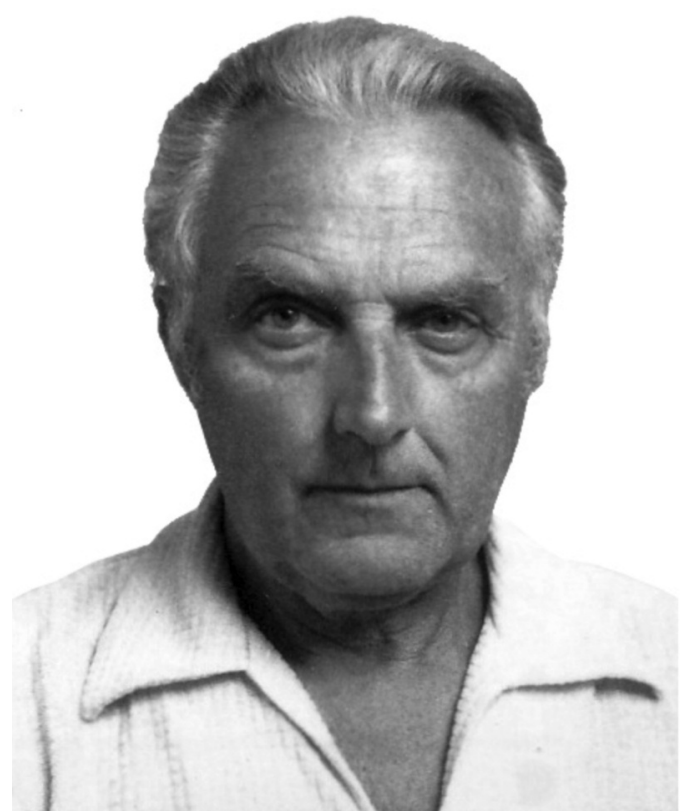

Figure 3. John M. Gillett, 1982. Photo provided by the Gillett family.

ically important species, focused on North American species but also extended worldwide. Jack described three new species and three new subspecies that are currently still recognized for North America: Dedecker's Clover (Trifolium dedeckerae J. M. Gillett); Rollins' Clover (Trifolium rollinsii J. M. Gillett); Siskiyou Clover (Trifolium siskiyouense J. M. Gillett); Beatley's Clover (Trifolium andersonii A. Gray ssp. beatleyae J. M. Gillett); Cascade Clover (Trifolium eriocephalum Nuttall ssp. cascadense J. M. Gillett); Martin's Clover (Trifolium eriocephalum Nuttall ssp. martinii J. M. Gillett). (It is interesting, and potentially confusing, that another Gillett, unrelated to Jack (Jan B. Gillett, 1911-1985), has also published new species of clovers.) Jack also described as new the Great Lakes Wheatgrass (Agropyron psammophilum J. M. Gillett \& H. Senn), which was subsequently transferred to the genus Elymus as a subspecies (Elymus lanceolatus ssp. psammophilus (J. M. Gillett \& H. Senn) Á. Löve).

Over the years, Jack was a member of a number of scholastic and learned societies: Sigma Xi, International Association for Plant Taxonomy, American Society of Plant Taxonomists, the New England Botanical Club, the California Botanical Society, the Canadian Botanical Association, Société botanique du Québec, the Explorers Club of New York, and the Ottawa FieldNaturalists' Club (OFNC).

Jack was a long-time member of the OFNC, beginning in 1946 when he was a summer student at the CEF. He served on its council from 1958 to 1970 in 
various capacities, including treasurer, auditor, and chair of the Publications Committee. He also compiled a comprehensive index to the Transactions of the Ottawa Field-Naturalists' Club and to The Ottawa Naturalist. In 1996, Jack received the Anne Hanes Natural History Award from the OFNC. This was given for his outstanding contributions to knowledge of the natural history of the Ottawa Valley through publications and long service on the OFNC council, club field excursions, and his friendly and open nature to both professional and would-be botanists. In 2000, he was awarded honorary membership in the OFNC (Brodo et al. 2001).

Jack met his first wife, Gladys Isabel Proulx (of Aylmer, Quebec, 1927-2001), while playing tennis and being soundly trounced. Her tennis skills apparently made a lasting impression on Jack. They were married 1 September 1956. Jack and Gladys had two children, Peter (1958), who became a visual artist and resides in Toronto with his partner Alma Roussy, and Kimberley (1960). Kimberley (Burnett) is a retired chartered professional accountant (CPA, CA) living in Ottawa with her husband François Gouin (CPA, CA). Kimberley has a daughter, Shannon Burnett, a Toronto special effects make-up artist for film and TV, who is married to Michael Echlin, also a visual artist. Gladys died on 20 July 2001 after a long battle with hepatitis C, contracted from a blood transfusion.

Jack was a man of many interests. He played piano, both classical and show tunes, and collected stamps and minerals. His "rock collection" was sufficiently extensive that his neighbours constructed a "mineral garden" with his collection when his house was sold and the garage was emptied of its contents. Jack was highly curious and fascinated by diverse topics, ranging from quantum physics to the politics of light-rail travel. He loved trains of all kinds and studying languages. His bookcase contained many instruction manuals, including French, Latin, Italian, Spanish, Chinese, Cree, Inuit, and Russian. He could nap readily, anywhere, anytime, and loved skinny-dipping, picnics in cemeteries, garage sales, and Saturday house shopping. Rain or shine, with kids in the back seat, "professional house shoppers" Jack and Gladys would head out on their weekly Saturday tours. In 45 years, they never did make another purchase (Kimberley Burnett, personal communication).

Jack met his second wife, Elizabeth Snowdon in 2002, through his friend Michael Smithson, another model-train enthusiast, who was Elizabeth's brother. Jack, who often had dinner with Michael and his wife, met Elizabeth at such a gathering while she was visiting from New Zealand. They obviously took a shine to each other because when Elizabeth challenged Jack to visit her in New Zealand, he promptly did so, arriving several weeks later. Over the next 12 years, they spent six months a year there, avoiding Canadian winters, and six months of the warm seasons at Jack's home. The latter years, however, were spent at Riverpark Place Retirement Residence, Ottawa.

They married in 2007 under perhaps typical Jacklike circumstances. Jack, being a fun-loving individual, took Elizabeth one morning to the "post office," actually the Ottawa City Hall, where he inquired where one could get married. When Jack was informed that he was at the right place, Elizabeth asked: "Who are you getting married to Jack?" "You, of course" said Jack. So it was on the morning of 15 October 2007 that Jack and Elizabeth Snowdon-Gillett were married and celebrated with a simple wedding breakfast - a cup of soup at Tim Horton's, Jack's favourite coffee shop chain (Elizabeth Snowdon-Gillett, personal. communication).

The passion for travel and exploring that was in Jack's blood had taken him, earlier in his career, beyond North America and Mexico, to such places as Columbia, Costa Rica, Venezuela, Hawaii, and Europe. He now continued his explorations with Elizabeth on a cruise around Australia, tours of New Zealand, and onward to Fiji, Bali, and Samoa. Their attempts at camping in New Zealand resulted in some memorable moments.

Elizabeth suggested they camp while touring New Zealand, but Jack said he was "too old for camping." Nevertheless, they did buy a tent and, with considerable effort and time, managed to erect it on their first try. This occasion became a source of amusement for fellow campers at the site who set up their lawn chairs to watch the unfolding event that resulted in the tent, initially, being erected inside out. Putting their tea cups aside, the onlookers gave them a round of applause. Subsequent camping efforts went more smoothly with a notable exception. While visiting Rotorua, the thermal capital of New Zealand, and not relishing being cold and uncomfortable at night, they pitched their tent in an area where the ground was warmed by a hot underground stream. Unfortunately, their inflated mattress collapsed in the dead of night from the excessive heat build-up under it. They couldn't find a thing in the dark, but got a great laugh out of it (Elizabeth Snowdon-Gillett, personal communication).

Jack died peacefully on Saturday, 27 December 2014 in his 97 th year (Figure 4). He is survived by his wife Elizabeth Snowdon-Gillett, daughter Kimberley, son Peter, and granddaughter Shannon. Many fond memories were made and are cherished by Jack's immediate family and by his extended family in New Zealand. Jack's professional contributions to taxonomy and floristics and his amiable assistance to others reflect a life full of achievements. As Kimberley and Peter remarked at his memorial service (5 January 2015), their father was a great adventurer with a true zest for life and an eagerness to experience all that life has to offer. 


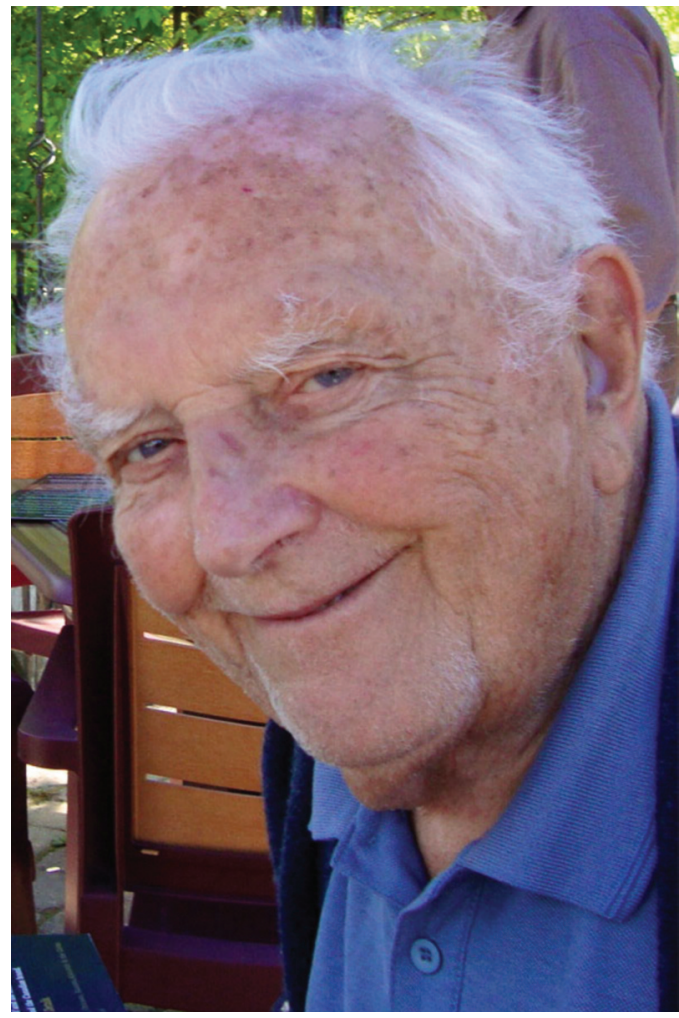

FIGURE 4. John M. Gillett. Family photo: 31 May 2014.

\section{Acknowledgements}

Much of the personal history and anecdotes presented here, which reflect the contributions of Kimberley, Peter, and Elizabeth, are gratefully acknowledged. I am also indebted to local botanists and colleagues of Jack, especially Dan Brunton, Paul Catling, Stephen Darbyshire, and Ted Mosquin, for discussions and contributions related to Jack's activities with the Ottawa Field-Naturalists' Club, the timeline of his research activities, bibliographic compilation of his publications on file at the Central Experimental Farm, Agriculture and Agri-Food Canada, and anecdotes related to fieldwork. Thanks also to the Canadian Museum of Nature, and especially Chantal Dussault, head, archives and library, for providing a scan of Jack's 1974 photo, and to Stephen Haber for photoshop improvements of original black and white images. Comments on an earlier draft by reviewers George Argus, Daniel Brunton, Paul Catling, and Irwin Brodo are also appreciated.

\section{Literature Cited}

Brodo, I. M., C. Hanrahan, S. Darbyshire, and S. Thomson. 2001. The Ottawa Field-Naturalists' Club Awards, April 2001. Canadian Field-Naturalist 115: 728-731.

Cody, W. J., D. B. O. Savile, and M. J. Sarazin. 1986. Systematics in Agriculture Canada at Ottawa 1886-1986.
Biosystematics Research Centre Historical Series No. 28. Agriculture Canada, Ottawa, Ontario, Canada. 81 pages.

\section{Bibliography of John M. Gillett}

Gillett, J. M. 1952. A revision of the North American species of Gentianella. Ph.D. thesis, Washington University, St. Louis, Missouri, USA.

Gillett, J. M. 1954. A plant collection from the Mealy Mountains, Labrador. Canadian Field-Naturalist 68: 118-122.

Gillett, J. M. 1954. Plants collected in the vicinity of Marmora. Canada Department Agriculture, Science Service, Botany and Plant Pathology Division, Ottawa, Ontario, Canada. 37 pages.

Dore, W. G., and J. M. Gillett. 1955. Botanical survey of the St. Lawrence Seaway area in Ontario. Botany and Plant Pathology Division, Science Service, Canada Department of Agriculture, Ottawa, Ontario, Canada. 115 pages.

Gillett, J. M. 1957. A revision of the North American species of Gentianella. Annals of the Missouri Botanical Garden 44: 195-269.

Gillett, J. M. 1958. Checklist of plants of the Ottawa District. Botany and Plant Pathology Division, Science Service, Canada Department of Agriculture, Ottawa, Ontario, Canada. 89 pages.

Gillett, J. M. 1959. A revision of Bartonia and Obolaria (Gentianaceae). Rhodora 61: 43-62.

Gillett, J. M. 1960. The flora of the vicinity of the Mereweather Crater, Northern Labrador. Canadian FieldNaturalist 74: 8-27.

Gillett, J. M. 1960. The family position of Moullava Adanson. Taxon 9: 152.

Gillett, J. M., and H. A. Senn. 1960. Cytotaxonomy and infraspecific variation of Agropyron smithii Rydb. Canadian Journal of Botany 38: 848-860.

Gillett, J. M., and H. A. Senn. 1961. A new species of Agropyron from the Great Lakes. Canadian Journal of Botany 39(5): 1169-1175.

Gillett, J. M. 1963. The gentians of Canada, Alaska and Greenland. Publication 1180. Research Branch, Canadian Department Agriculture, Ottawa, Ontario, Canada. 99 pages.

Gillett, J. M. 1963. The flora of Goose Bay, Labrador. Canadian Field-Naturalist 77: 131-145.

Gillett, J. M. 1965. Taxonomny of Trifolium: five American species of section Lupinaster (Leguminosae). Brittonia 17: 121-136.

Mosquin, T., and J. M. Gillett. 1965. Chromosome numbers in North American Trifolium (Leguminosae). Brittonia 17: 136-143.

Gillett, J. M. 1966. Type collections of Trifolium in the Greene Herbarium at Notre Dame. American Midland Naturalist 76: 468-474.

Dunn, D. B., and J. M. Gillett. 1966. The lupines of Canada and Alaska. Monograph no. 2. Research Branch, Canada Department Agriculture, Ottawa, Ontario, Canada. 89 pages.

Parups, E. V., J. R. Proctor, R. Meredith, and J. M. Gillett. 1966. A numero-taxonomic study of some species of Trifolium, section Lupinaster. Canadian Journal of Botany 44 : 1177-1182.

Gillett, J. M. 1967. Hedysarom occidentale Greene (Leguminosae) new to Canada. Canadian.Field-Naturalist 81: 224. 
Gillett, J. M. 1967. A suggestion to avoid embarrassing transfers. Taxon 16: 465-466.

Gillett, J. M. 1967. Explorer's corner — Mud Pond. Trail \& Landscape 1: 95-97.

Baum, B. R., and J. M. Gillett. 1967. The identity of Urtica hulensis Feimbr. Österreichische botanische Zeitschrift 114: 320-323.

Löve, A. Editor. 1967. IOPB chromosome number reports X. Taxon 16: 146-157. Miscellaneous chromosome counts provided by J. M. Gillett and T. Mosquin.

Gillett, J. M. 1968. The systematics of the Asian and American populations of Fauria crista-gallii (Menyanthaceae). Canadian. Journal of. Botany 46: 92-96.

Gillett, J. M. 1968. Explorer's corner - Haycock Island. Trail \& Landscape 2: 107-109.

Gillett, J. M. 1968. The milkworts of Canada. Monograph no. 5. Research Branch, Canada Department of Agriculture, Ottawa, Ontario, Canada. 24 pages.

Gillett, J. M. 1969. Taxonomy of Trifolium (Leguminosae) II. The T. longipes complex in North America. Canadian Journal of Botany 47: 93-113.

Gillett, J. M. 1969. A refinement of Article 43. Taxon 18: 348.

Gillett, J. M. 1970. Cyperus fuscus L. new to Canada. Canadian. Field-Naturalist 85: 190.

Gillett, J. M. 1970. What is citron? Greenhouse, Garden, Grass 9(2): 1-2.

Gillett, J. M. 1970. Gleanings from yesteryear. Trail \& Landscape 4: 93.

Gillett, J. M. 1971. Taxonomy of Trifolium (Leguminosae) III. T. eriocephalum Nutt. Canadian Journal of Botany 49: 395-405.

Gillett,J. M. 1971. The native rhododendrons of Canada and Alaska. Greenhouse, Garden, Grass 10(3): 35-45.

Gillett, J. M. 1971. A new Ottawa District station for cliff brake, Cryptogramma stelleri. Trail \& Landscape 5: 130132.

Gillett, J. M. 1972. Two new records for pinedrop (Pterospora andromedea Nutt.) for Ontario and Quebec. Canadian Field-Naturalist 86: 172-175.

Gillett, J. M. 1972. Taxonomy of Trifolium (Leguminosae) IV. The American species of section Lupinaster (Adanson) Seringe. Canadian Journal of Botany 50: 1975-2007.

Gillett, J. M. 1972. Two new species of Trifolium from California and Nevada. Madrono 21: 451-455.

Gillett, J. M. 1973. Spring flowers of the National Capital region/Fleurs printanières de la region decapitale nationale. Canada Department Agriculture/National Capital Commission, Ottawa, Ontario, Canada. 116 pages.

Gillett, J. M., and T. S. Cochrane. 1973. Preliminary reports on the flora of Wisconsin, no. 63. The genus Trifolium - The clovers. Transactions of the Wisconsin Academy of Science 61: 59-74.

Gillett, J. M., I. J. Bassett, and C. W. Crompton. 1973. Pollen morphology and its relationship to the taxonomy of North American Trifolium species. Pollen \& Spores 15: 91-108.

Aiken, S., and J. M. Gillett. 1974. The distribution of aquatic plants in selected lakes of Gatineau Park, Quebec. Canadian Field-Naturalist 88: 437-448.

Love, A. Editor. 1975. IOPB chromosome number reports L. Taxon 24: 671-678. Miscellaneous chromosome number reports provided by J. M. Gillett.
Gillett, J. M. 1976. Plants of Coats Island, Hudson Bay, Keewatin District, Northwest Territories. Canadian FieldNaturalist. 90: 390-396.

Gillett, J. M. 1976. A new species of Trifolium (Leguminosae) from Baja California, Mexico. Madroño 23: 334 337.

Gillett, J. M., and M. J. Shchepanek. 1977. Isotypes and syntypes in a Lindheimer Texas collection at the National Herbarium of Canada, Ottawa. Taxon 26: 429-434.

Gillett, J. M., and D. J. White. 1978. Checklist of Vascular P lants of the Ottawa-Hull Region, Canada/Liste des plantes vasculaires de la region d'Ottawa-Hull, Canada. National Museum Natural Sciences, National Museums of Canada, Ottawa, Ontario, Canada. 155 pages.

Gillett, J. M. 1979. New combinations in Hypericum, Triadenum and Gentianopsis. Canadian Journal of Botany 57: $185-186$.

Gillett, J. M. 1980. Transactions of the Ottawa Field-Naturalists' Club and the Ottawa Naturalist - INDEX. Special publication no. 2. Ottawa Field-Naturalists' Club, Ottawa, Ontario, Canada. 195 pages.

Gillett, J. M. 1980. Taxonomy of Trifolium (Leguminosae) V. The perennial species of section Involucrarium. Canadian Journal of Botany. 58: 1425-1448.

Gillett, J. M., and N. K. B. Robson. 1981. The St. John'sworts of Canada (Guttiferae). Publications in botany 11. National Museums of Canada, Ottawa, Ontario, Canada. 40 pages.

Gillett, J. M. 1983. Plants: from the field to the herbarium. Pages 161-167 in Proceedings of the 1981 Workshop on Care and Maintenance of Natural History Collections. Syllogeus 44 of the Society for the Preservation of Natural History Collections. Edited by D. J. Faber. National Museums of Canada, Ottawa, Ontario, Canada. 196 pages.

Gillet, J. M., and P. M. Catling. 1983. History, geomorphology and vegetation of Gatineau Park. Pages 7-20 in The Arthropods of Gatineau Park. Agriculture Canada Technical Bulletin. Edited by J. D. Lafontaine, V. M. BehanPelletier, J. M. Campbell, K. G. A. Hamilton and D. M. Wood. 463 pages. (The Gillet and Catling chapter was reprinted in 1994 in Trail and Landscape 28(4): 129-138.)

Taylor, N. L., J. M. Gillett, and N. Giri. 1983. Morphological observations and chromosome numbers in Trifolium L. section Chronosemium Ser. Cytologia 48: 671-677.

Bridgland, J., and J. M. Gillett. 1984. Vascular plants of the Hayes Sound region, Ellesmere Island, Northwest Territories. Canadian Field-Naturalist 97: 279-292.

Gillett, J. M. 1985. Taxonomy and morphology. Pages 7-47 (plates) in Clover Science and Technology. Edited by $\mathrm{N}$. L. Taylor. American Society Agronomists, Madison, Wisconsin. Monograph 25.

Gillett, J. M., and R. R. Smith. 1985. Germplasm exploration and preservation. Pages 445-456 in Clover Science and Technology. Monograph 25. Edited by N. L. Taylor. American Society of Agronomy, Madison, Wisconsin, USA.

Taylor, N. L., and J. M. Gillett. 1988. Crossing and morphological relationships among Trifolium species closely related to strawberry and Persian clover. Crop Science 28: 636-639. 
Watson, G. D. 1990. Palaeo-Indian and archaic occupations of the Rideau Lakes. Ontario Archaeology 50: 7. Champlain sea boundaries provided by J. M. Gillett and M. J. Shchepanek.

Gillett, J. M. 1991. Goldenrods. Trail \& Landscape 25: 114-121.

Gillett, J. M. 1993. The Liliaceae and Smilacaceae of the Ottawa District. Trail \& Landscape 27: 22-37.

Gillett, J. M. 1994. Rushes of the Ottawa District. Trail \& Landscape 28: 78-85.

Gillett, J. M., and P. M. Catling. 1994. Vegetation and topography of Gatineau Park. Trail \& Landscape 28: 129-138.
Gillett, J. M. 1995. Asters of the Ottawa District. Trail \& Landscape 29: 89-99.

Gillett, J. M. 1995. Thoroughworts of the Ottawa District. Trail \& Landscape 29: 100-103.

Gillett, J. M., N. M. Taylor, and M. Collins. 2001. The World of Clovers. Iowa State University Press, Ames, Iowa, USA. 457 pages.

Gillett, J. M. Trifolium. In Flora of North America, North of Mexico, volume 10-11. Edited by Flora of North America Editorial Committee. Oxford University Press, New York, New York, USA. In press.

Received 22 January 2015

Accepted 4 February 2015 